which has proved to be one of the best additions to garden plants which has ever been made. The first plant obtained by this cross was called $P$. Lemoinei; it is a perfectly hardy shrub from four to six feet high and broad, with slender stems which bend under the weight of the countless flowers which are intermediate in size between those of the parents and retain the fragrance of those of $P$. microphyllus. There are at least a dozen distinct forms of this hybrid made by Lemoine, varying considerably in the size of the flowers and in the time of flowering. One of the handsomest of these plants, perhaps, is called Candelabre, which is a dwarf with flowers larger than those of either of its parents, an inch and a half wide, with petals notched on the margins and without the fragrance of its parents. Other distinct forms equally hardy and handsome are Avalanche, Boule d'Argent, Bouquet Blanc, Erectus, Fantasie, Gerbe de Neige and Mont Blanc.

Neillia sinensis. This is the only member of a genus of the Rose Family related to Spiraea which has flowered in the Arboretum. It is a native of western China where it was collected by Wilson and introduced into cultivation through the Arboretum. It is a tall hardy shrub with gracefully spreading and drooping branches, light green, incisely cut, pointed leaves from an inch and a half to two inches long, and clear pink flowers about half an inch in length, in short terminal racemes. It is one of the handsomest and most interesting of the hardy shrubs introduced by Wilson from w.estern China.

Rosa Marretii is blooming remarkably this year. It is a tall, broad shrub with arching stems, pale green leaves and large pink flowers. It is a native of northern Hokkaido and of Saghalin where it was discovered by the late Abbé Faurie who sent seeds to the Arboretum in 1908. This plant, which is still rare in cultivation, promises to be a good addition to the single-flowered Roses which can be successfully grown in this climate. One of the hardiest and best growing of the new Roses, Rosa bella, was raised at the Arboretum from seeds collected by Purdom in northern China, and is a plant which when better known will be popular. It is a large shrub with bright red flowers an inch and a half in diameter, and bright red fruit. It is with the other Chinese plants on Bussey Hill.

Rosa multiflora cathayensis is again covered with its great clusters of pink flowers and expanding flower-buds. The Chinese representive of the white-flowered $R$. multiflora of Japan, it is one of the most beautiful Roses and interesting as the wild type from which the Chinese derived the now well known Crimson Rambler Rose and another old-fashioned garden Rose, the Seven Sisters Rose $(R$. multiflora platyphylla). 


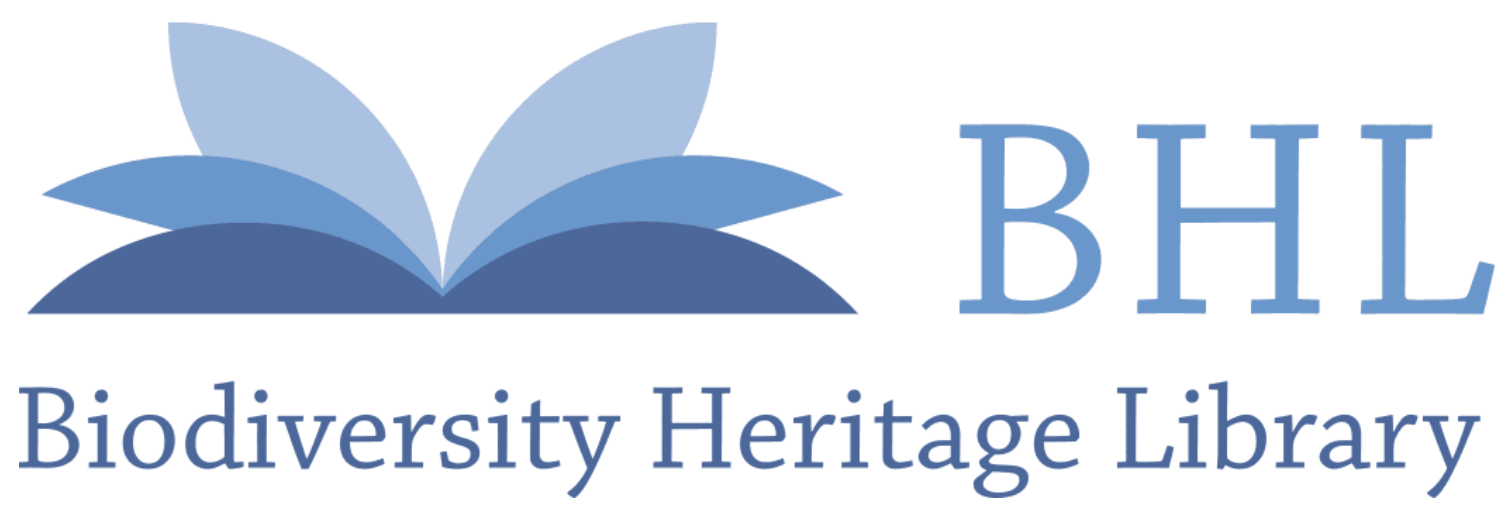

1924. "Rosa multiflora cathayensis." Bulletin of popular information - Arnold Arboretum, Harvard University 10(10), 40-40. https://doi.org/10.5962/p.321482.

View This Item Online: https://www.biodiversitylibrary.org/item/216912

DOI: https://doi.org/10.5962/p.321482

Permalink: https://www.biodiversitylibrary.org/partpdf/321482

\section{Holding Institution}

Harvard University Botany Libraries

\section{Sponsored by}

BHL-SIL-FEDLINK

\section{Copyright \& Reuse}

Copyright Status: Public domain. The BHL considers that this work is no longer under copyright protection.

Rights Holder: Arnold Arboretum of Harvard University

This document was created from content at the Biodiversity Heritage Library, the world's largest open access digital library for biodiversity literature and archives. Visit BHL at https://www.biodiversitylibrary.org. 